\title{
Do speakers of Dutch use their knowledge of German while processing written Danish words?
}

\author{
Femke Swarte, Anja Schüppert and Charlotte Gooskens \\ University of Groningen
}

This paper elaborates on a factor that plays a role in receptive multilingualism, namely the influence of a second language (L2). We investigated whether knowledge of German can help Dutch people to decode written Danish words when they do not know any Danish. We instructed 32 participants with Dutch as a native language (L1) and different levels of proficiency in German as an L2 to translate 42 written Danish words into Dutch. The results showed that participants with a higher level of German performed better on this translation task. Furthermore, our data provides evidence for the existence of a 'foreign language mode', i.e. the knowledge of German as an L2 seems to take over from the knowledge of the L1 if the participants' proficiency in German is high.

Keywords: mutual intelligibility, receptive multilingualism, cross-linguistic influence, foreign language mode, psycholinguistics

\section{Introduction}

Languages are considered to be mutually intelligible if their speakers can communicate while each speaking their own language without knowing each other's language. Research has uncovered a great number of factors that play a role in mutual intelligibility among closely related languages. These factors can be linguistic, i.e. related to specific features of the languages in question, such as lexical and phonetic differences between languages (Van Bezooijen \& Gooskens 2005; Gooskens 2007; Tang \& van Heuven to appear), but also extra-linguistic, i.e. not related to language-specific features but to situations outside the language, such as language attitudes and language contact (Delsing \& Lundin Åkesson 2005; Schüppert, Hilton \& Gooskens (to appear)). 
In this paper we investigate an extra-linguistic factor that affects mutual intelligibility, namely the influence of second language knowledge. Van Bezooijen, Gooskens \& Kürschner (2012) suggest that non-cognates can be correctly deciphered through knowledge of a second language (L2). As illustrated in Figure 1, speakers of Dutch would for example be able to correctly translate the Danish word bogstav into the Dutch non-cognate letter through the L2 German cognate Buchstabe. However, to date, no research has been carried out on this subject.

There is, however, comparable research from the area of $\mathrm{L} 2$ and third language (L3) acquisition. Since the 1950s research has been conducted on cross-linguistic influence (CLI) in second language acquisition, i.e. influence from the native language (L1) on the production of the L2 (Weinreich 1953; Odlin 1989). Since about 2000, there has been a growing interest in CLI in third language acquisition (Cenoz 2001; Hammarberg 2001). Although this is a relatively new branch of research, there is a consensus that there is a difference between L2 and L3 acquisition. Where L2-learners only have one language influencing their learning process, L3-learners know two or even more languages that can interfere with the L3 they are acquiring (Murphy 2003). In this paper we consider the most recently acquired foreign language as the L3. All previously acquired foreign languages are considered L2s.

In Sections 1.1 and 1.2, we provide a selection of factors that affect CLI in third language acquisition. In line with Murphy (2003), we differentiate between factors that are learner-based, i.e. factors that are learner-specific, and factors that are language-based, i.e. factors that are language-specific.

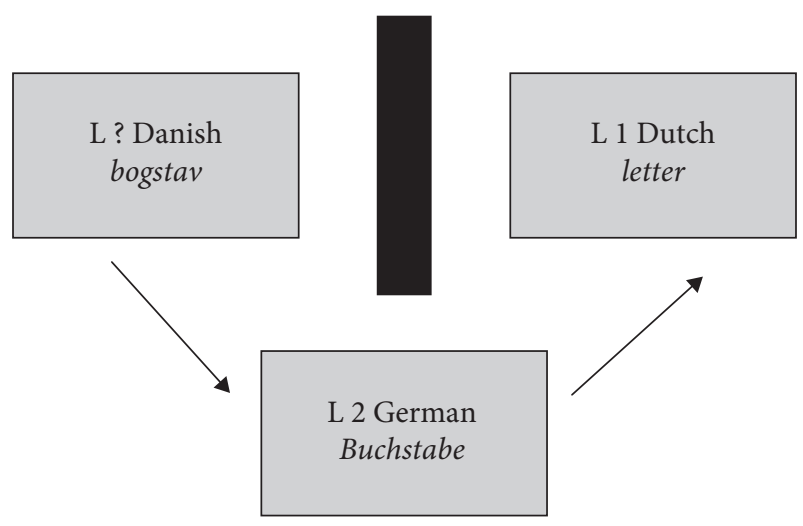

Figure 1. Decoding a non-cognate through cognates from a second language 


\subsection{Learner-based factors}

An important learner-based factor is the level of language proficiency of the learner. The lower the proficiency in the L3, the greater the influence of the L2 (Ringbom 1987; Hammarberg 2001). This is primarily the case for negative transfer, i.e. cases where information from the L1 and/or L2 is falsely transferred and leads to language mistakes in the production of the L3. Note, however, that certain forms of positive transfer, i.e. cases where information is correctly transferred from the L1 and/or L2 into the L3, such as the use of cognate knowledge, can also occur when the proficiency in the L3 is high (Odlin 1989). When the L3 proficiency is high, the speaker will be more likely to recognise cognates between the L 2 and L3. The influence of language proficiency also works the other way around. There can only be CLI from the L2 in L3 acquisition when the learner has certain knowledge of the L2 (Hammarberg 2001).

Language contact is a second important learner-based factor. The more exposure to the L3 a person has had, the less language transfer from other languages occurs. This influence is even stronger in L2 acquisition (Dewaele 2001). Of course, this factor interacts to a large extent with language proficiency (Murphy 2003), as more exposure to a language might often lead to a better proficiency in that language.

A last important learner-based factor in the context of this paper is the language mode a person finds himself in (Grosjean 2001). According to Selinker \& Baumgartner-Cohen (1995), who introduced the foreign language mode theory, L3 learners rely more on their L2 knowledge than on their L1 knowledge, when the L2 proficiency is high. The foreign language mode particularly affects the lexical domain. In line with this theory, Dewaele (1998) showed that L3 French learners with L1 Dutch and L2 English show a great amount of CLI in the production of lexical items. Dewaele finds that his participants more often transfer knowledge from L2 English rather than from L1 Dutch into L3 French (Dewaele 1998: 486).

In our paper we also investigate whether we can observe a foreign language mode, i.e. whether it is the case that participants with a high proficiency of German use more knowledge from their L2 German than from their L1 Dutch while translating Danish words than lower proficiency speakers.

\subsection{Language-based factors}

An important language-based factor is the typological similarity of the languages involved (Singh \& Carroll 1979; Bartelt 1989). Tremblay (2006) investigated CLI from L1 English and L2 French on L3 German. She found a greater influence from L1 English on L3 German than from L2 French. She sees the closer relationship of 
English and German, as opposed to French, as a possible explanation for this finding, but notes that the proficiency of French of her participants might have been too low, which also could explain the results.

Most of the investigations summarised above describe cases of negative transfer. In this paper, however, we explore to which extent knowledge of an L2 can lead to positive transfer, i.e. whether knowledge of an $\mathrm{L} 2$ can help to understand an unknown but related language better. More precisely, we investigate here whether native speakers of Dutch activate their knowledge of German while translating written Danish words, some of which have cognates in Dutch, others in German. Therefore, we are interested in cognate pairing. According to Carroll (1992), cognates are processed by combining information from the L1 lexicon with the L2 stimulus word while at the same time ignoring differences between the L1 and L2. When this process is successfully completed, it leads to positive transfer, i.e. a correct translation of the stimulus word. When the process is not successfully completed, it leads to negative transfer, i.e. an incorrect translation of the stimulus word.

In our experiment, however, we are interested in the influence of a second language. Therefore, our participants have two languages - namely Dutch and German - they can use to translate the unknown Danish stimulus word. So, assuming the cognate pairing process is successfully completed, a Danish stimulus word that has a cognate in Dutch will lead to the activation of the Dutch lexicon, while a Danish stimulus word that has a cognate in German will lead to the activation of the German lexicon. Lemhöfer, Dijkstra \& Michel (2004) show that it is indeed possible to activate more languages at the same time while processing cognates. However, cognate recognition is only possible when the language proficiency is high enough. Van Hell \& Dijkstra (2002) report for example that participants with a high level of English and a low level of French are faster in processing cognates from English than from French.

The three languages in question in our investigation are closely related and a large part of their vocabularies has a common etymology. Dutch, German and Danish are all Germanic languages. However, Danish belongs to the North Germanic language branch and German and Dutch both belong to the West Germanic language branch. That means that German and Dutch are more closely related to each other than they are to Danish.

\section{Aims}

The purpose of our investigation is twofold. First of all, we investigate whether knowledge of a second language can positively influence the processing of an 
unknown but related language. More precisely, we are looking at university students with Dutch as their native language and different levels of proficiency in German as L2 who are confronted with Danish as the unknown related language.

Secondly, we explore whether the L1 or the L2 has a greater influence on the processing of the unknown related language when the participant's proficiency in the L2 is high, that is, whether there is a foreign language mode.

We will answer those questions by reporting on the results of our experiment in which Dutch participants with different proficiency levels in German translate Danish words. Half of the words only have cognates in German, the other half only has cognates in Dutch. We hypothesise that participants with a high level of German translate more Danish-German cognates correctly than participants with a low level of German.

\section{Method}

\subsection{Participants}

In total, 32 students from the Faculty of Arts of the University of Groningen (The Netherlands) took part in the study. All participants spoke only Dutch as a native language and none of them had any knowledge of Danish. Among the participants were 23 women and 9 men. All participants were between 18 and 29 years old.

The participants' level of German was determined by the percentage of German control words they translated correctly (cf. Section 3.3). The participants translated on average 59\% of the German words correctly. All participants who had a score higher than $59 \%$ were considered to have a high proficiency in German and all participants who had a score below 59\% were considered to have a low proficiency in German. According to this criterion, 18 participants had a high level of German and 14 participants had a low level of German.

\subsection{Stimulus material}

The stimulus material consisted of 28 Danish singular nouns. 14 of those words only had cognates in German and not in Dutch (e.g. Danish bogstav, German Buchstabe, Dutch letter, 'letter'), henceforth referred to as the Danish-German cognate list. 14 words only had cognates in Dutch and not in German (e.g. Danish gylp, Dutch gulp, German Reißverschluss, 'zipper') henceforth referred to as the Danish-Dutch cognate list. We also included 14 Danish control words that did not have cognates in either Dutch or German (e.g. Danish pige, Dutch meisje, German Mädchen, 'girl'). They were used to identify participants who had some knowledge 
of Danish. Those words were not taken into account in the analyses. None of the words used had any cognates in English. A list with all words used in our experiment can be found in Appendix A.

There were two versions of the experiment. In the first version, the participants just translated the isolated Danish words. Participants who performed the second version of the experiment got a hint in the form of a semantic category in which the word fitted, as shown in Table 1.

Table 1. Example of a word and its semantic category

\begin{tabular}{|l|l|l|}
\hline $\begin{array}{l}\text { Danish stimulus } \\
\text { word }\end{array}$ & Semantic category & $\begin{array}{l}\text { Correct Dutch } \\
\text { translation }\end{array}$ \\
\hline pakhus & gebouw (building) & pakhuis \\
\hline
\end{tabular}

In order to keep the Danish-German and the Danish-Dutch cognate lists as comparable as possible, the orthographic distance between both lists was kept constant. This was established by calculating the orthographic distance between each Danish stimulus word and its Dutch or German cognate by means of a Levenshtein distance. The Levenshtein procedure is based on the number of steps (inserting, deleting or substituting a character) that has to be taken to go from one (in this case) orthographic form to the other (Gooskens, Heeringa \& Beijering 2008).

Figure 2 shows an example of this procedure. Here, the orthographic distance between the Danish word gylp (English 'zipper') and its Dutch cognate gulp is calculated. To transform the Danish form into the Dutch form, the $y$ is replaced by a $u$ and there are no deletions or insertions. The number of operations (1) is divided by the length of the alignment (4), which leads to a distance of $25 \%$.

The results of the Levensthein distance calculations showed that the mean orthographic distance is the same for the Danish-Dutch and the Danish-German cognates. The Danish-Dutch cognates had a mean orthographic distance of $30.6 \%$ $(S D=19.3)$. The Danish-German cognates had a mean orthographic distance of $28.5 \%(S D=20.7)$. An independent samples t-test showed that this difference is not significant $(t(26)=-.25, p=0.79)$.

Additionally, the reliability of the semantic categories was kept constant for both cognate lists. This distance was measured by means of an opinion scaling test.

$$
\begin{aligned}
& \text { g y } 1 \text { p } \\
& \text { g u } 1 \text { p } \\
& 1 \\
& 1 / 4=25 \% \text { difference }
\end{aligned}
$$

Figure 2. Example of the Levenshtein procedure 
In this test 20 Dutch participants received a list with the Dutch translations of the 42 Danish words that were going to be used in the real experiment along with a semantic category. These semantic categories were determined by the researchers. The participants had to indicate how well they thought each word fitted its semantic category on a scale from 1 (not at all) to 5 (very well). The results showed that the reliability of the semantic categories is the same for all three groups of stimulus words. All three lists had a mean of 3.8 (SD Danish list $=0.71, S D$ Danish-Dutch list $=0.64$, SD Danish-German list $=0.68$ ) on a scale from 1 to 5 and an ANOVA showed that the lists did not differ significantly $(F(2,39)=0.11, p=0.9)$.

\subsection{Procedure}

Before the experiment started, the participants were asked to fill in a list with questions about their personal background, including their age, sex, educational background and their knowledge of languages. Participants with another L1 than Dutch and participants with knowledge of Danish or any other Scandinavian language were excluded from the analysis.

After filling in the list with background questions, the participants saw the 42 written Danish stimulus words, which they had to translate into Dutch. The experiment was conducted with pen and paper. Half of the participants saw the list with the semantic categories as described in Section 3.2, the other half saw the list without the semantic categories. The purely Danish words, the Danish-German cognates and the Danish-Dutch cognates were presented in four different orders.

When the participants had finished translating the Danish words, they were presented with the same Danish-German cognates again, but this time in German. They were asked to translate the German words into Dutch. Their translation accuracy was taken as a measure of their level of German.

\subsection{Scoring of the data}

There were three possible scores the participants could get for the translation of each word. Correct translations were awarded 1 point and incorrect translations 0 points. Half-correct translations were scored as 0.5 points. These were cases where the singular noun was translated into the plural form (e.g. Danish vante ('mitten') was translated into Dutch wanten ('mittens')) or into a cognate from a different word class (e.g. Danish fjernsyn ('television') was translated into Dutch tv kijken ('to watch television')). This way of scoring was the same for the Danish stimulus words and for the German words the participants translated after the experiment in order to test their level of German. 


\section{Results}

\subsection{Does knowledge of German help?}

A repeated measures ANOVA showed that participants with a high proficiency in German indeed performed significantly better at translating the written Danish words than participants with a low proficiency in German. Table 2 illustrates this finding. More specifically, the participants with a high level of German proficiency translated significantly more Danish-German cognates correctly than participants with a low level of German. As for the Danish-Dutch cognates, both groups performed nearly the same.

Table 2. The mean scores (\%) of both groups in the two conditions

\begin{tabular}{lll}
\hline & Low level of German & High level of German \\
\hline Danish-German cognates & $M=21, S D=13.8$ & $M=60.1, S D=12.4$ \\
Danish-Dutch cognates & $M=48.2, S D=12.4$ & $M=50.8, S D=13.6$ \\
\hline
\end{tabular}

4.2 Can we observe a foreign language mode in the data?

The results of a repeated measures ANOVA showed that a foreign language mode can be observed in our data. As can be seen from Figure 3, participants with a low level of German translated more Danish-Dutch cognates than Danish-German cognates correctly. However, the results are reversed for the participants with a high level of German. They translated more Danish-German cognates than DanishDutch cognates correctly. The interaction effect between level of German and condition was significant $(F(1,28)=64.7 p<0.001)$. Our data thus confirms findings by Grosjean (2001), Selinker \& Baumgartner-Cohen (1995) and Dewaele (1998).

Interestingly, the influence of the foreign language mode seems to be smaller when the words are put in a context. Figure 4 shows a comparison between the participants who translated the written Danish words with the help of a semantic category to which a word belonged and the participants who translated the words without the semantic categories. There is still a foreign language mode for the participants who translated the words with the semantic categories, but the effect appears to be smaller.

\section{Discussion and conclusion}

Firstly, we find that knowledge of German as L2 can help Dutch people to successfully process written Danish words. A factor that plays an important role is 


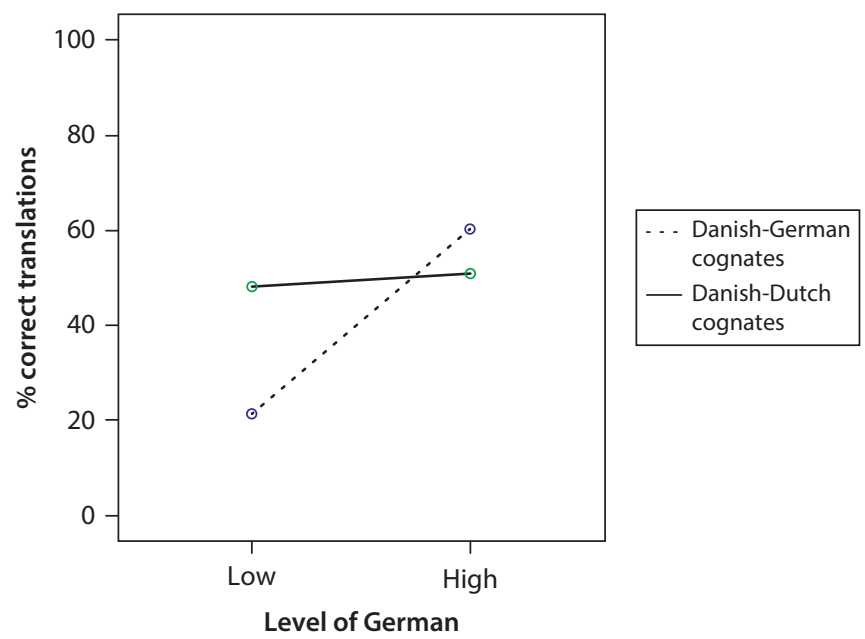

Figure 3. Translation accuracy (\%) in both conditions for participants with a low proficiency in German and participants with a high proficiency in German
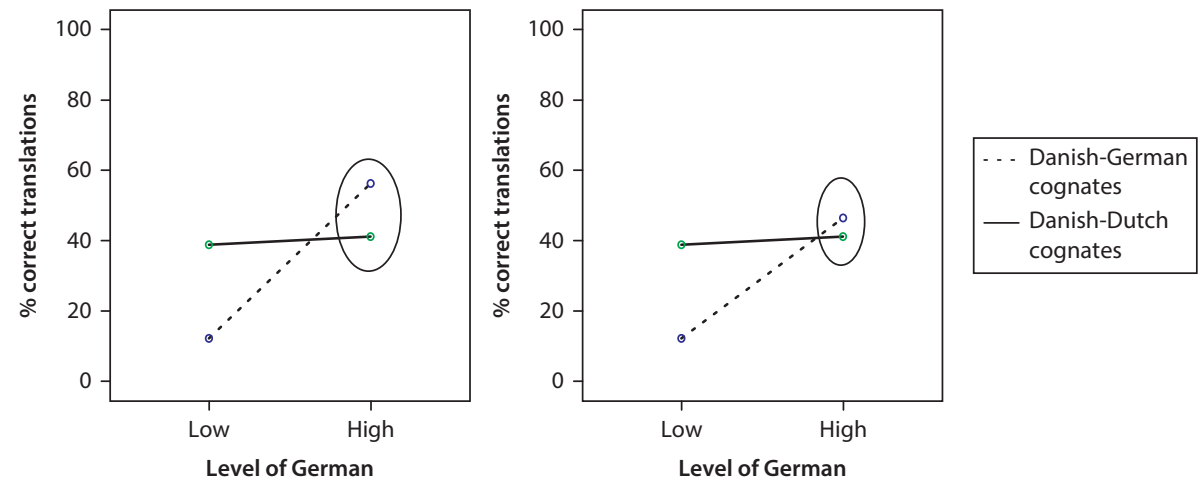

Figure 4. Translation accuracy (\%) for participants who translated the Danish words without the semantic categories (left graph) and the participants who translated the Danish words with the semantic categories (right graph)

the participant's proficiency in his or her L2. In our study, Dutch participants who have a high proficiency in German are more successful at translating written Danish words than the participants who have a low proficiency in German.

Secondly, our results suggest that there is a foreign language mode. Participants with a high proficiency in German translate less Danish-Dutch cognates than Danish-German cognates correctly. It seems that for participants with a high proficiency in German, their L2 is more influential than their native language, even when translating Danish-Dutch cognates. We think that this is due to the fact that the more proficient a person is in his L2, the more the L2 will compete with the L1. 
This is in line with findings by Sandoval, Gollan, Ferreira \& Salmon (2010), who tested English-speaking monolinguals and English-Spanish speaking bilinguals in semantic tasks, where they had to name as many words that belonged to a certain semantic category as possible within a certain time frame. The results showed that there is a cross-language competition in bilingual minds. Bilingual participants were slower and gave fewer correct answers than monolingual participants.

It is also striking that the influence of the foreign language mode gets significantly smaller when the words are placed into a context. The difference between the number of correctly translated Danish-Dutch and Danish-German cognates is significantly smaller for the participants who translated the words with the help of a hint in the form of a semantic category in which the word fitted than for the participants who translated the words without semantic categories. We think that this is due to the fact that the participants are pushed into the right direction when given the category to which the stimulus belongs. One example that illustrates this is the Danish word gab ('yawn') which has a Dutch cognate, gaap ('yawn'), but also a false friend in German, gab ('gave', the past tense of the verb to give). Since the orthography of the German false friend is closer to the Danish target word than the orthography of the Dutch cognate, it seems highly possible that participants with a high proficiency in German would translate the target word into gaf, the past tense of the verb to give in Dutch. However, the participants that took the experiment with the semantic categories, saw that the Danish target word gab belonged into the category slaap ('sleep'). This extra information probably prevented the participants from translating the target word into gaf, the Dutch equivalent of the German false friend $g a b$ ('gave').

Another aspect that might have contributed to the effect of the foreign language mode getting smaller when the words are placed into a context is the fact that the semantic categories were offered in Dutch. According to Grosjean (1998), the conversational context, including factors such as the language the communication takes place in and the conversational topic, has influence on the language mode the participants are in. It is therefore possible that offering the categories in Dutch might have pulled the participants out of the foreign language mode.

Multiple investigations have shown that spoken Danish is harder to understand than written Danish for speakers of other Scandinavian languages (cf. Maurud 1976). Anecdotal evidence claims that this is also the case for speakers of other Germanic languages. Therefore this experiment should be repeated with spoken Danish words to explore whether knowledge of German also helps there and if the same results concerning the foreign language mode are to be found. 


\section{References}

Bartelt, Guillermo. 1989. The interaction of multilingual constraints. In Hans W. Dechert \& Manfred Raupach (eds.), Interlingual processes, 157-177. Tübingen: Gunter Narr.

Bezooijen, Renée van \& Charlotte Gooskens. 2005. How easy is it for speakers of Dutch to understand spoken and written Frisian and Afrikaans, and why? Linguistics in the Netherlands 22. 13-24.

Bezooijen, Renée van, Charlotte Gooskens \& Sebastian Kürschner. 2012. Deens is makkelijker voor Friezen dan voor Nederlanders. Feit of fabel? In Piter Boersma, Th. Jensma Goffe \& Reinier Salverda (eds.), Philologia Frisica, 286-298. Leeuwarden: Fryske Akademy.

Carroll, Susanne E. 1992. On cognates. Second Language Research 8. 93-119.

Cenoz, Jasone 2001. The effect of linguistic distance, L2 status and age on cross-linguistic influence in third language acquisition. In Jasone Cenoz, Britta Hufeisen \& Ulrike Jessner (eds.), Cross-linguistic influence in third language acquisition: Psycholinguistic perspectives, 8-20. Clevedon: Multilingual Matters.

Dewaele, Jean-Marc. 1998. Lexical Inventions: French Interlanguage as L2 versus L3. Applied Linguistics 19(4). 471-490.

Dewaele, Jean-Marc. 2001. Activation or inhibition? The interaction of L1, L2 and L3 on the language mode continuum. In Jasone Cenoz, Britta Hufeisen \& Ulrike Jessner (eds.), Cross-linguistic influence in third language acquisition: Psycholinguistic perspectives, 90-114. Clevedon: Multilingual Matters.

Delsing, Lars-Olof \& Katarina Lundin Åkesson. 2005. Håller språket ihop Norden? En forskningsrapport om ungdomars förståelse av danska, svenska och norska. [Does the language keep together the Nordic countries? A research report of mutual comprehension between young speakers of Danish, Swedish and Norwegian.] Copenhagen: Nordiska ministerrådet.

Gooskens, Charlotte. 2007. The contribution of linguistic factors to the intelligibility of closely related languages. Journal of Multilingual and Multicultural Development 28(6). 445-467.

Gooskens, Charlotte, Wilbert Heeringa \& Karin Beijering. 2008. Phonetic and lexical predictors of intelligibility. International Journal of Humanities and Arts Computing 2 (1:2). 63-81.

Grosjean, François. 1998. Studying bilinguals: Methodological and conceptual issues. Bilingualism: Language and Cognition 1. 131-149.

Grosjean, François. 2001. The bilingual's language modes. In Janet L. Nicol (ed.), One mind, two languages: Bilingual language processing, 1-22. Oxford: Blackwell.

Hammarberg, Bjørn. 2001. Roles of L1 and L2 in L3 production and acquisition. In Jasone Cenoz, Britta Hufeisen \& Ulrike Jessner (eds.), Cross-linguistic influence in third language acquisition: Psycholinguistic perspectives, 21-41. Clevedon, UK: Multilingual Matters.

Hell, Janet G. van \& Ton Dijkstra. 2002. Foreign language knowledge can influence native language performance in exclusively native contexts. Psychonomic Bulletin \& Review 9(4). 780-789.

Lemhöfer, Kristin, Ton Dijkstra \& Marije C. Michel. 2004. Three languages, one ECHO: Cognate effects in trilingual word recognition. Language and Cognitive Processes 19(5). 585-611.

Maurud, Øivind. 1976. Nabospråksforståelse i Skandinavia. En undersøkelse om gjensidig forståelse av tale- og skriftspråk i Danmark, Norge og Sverige. [Neighbouring language comprehension in Scandinavia. An investigation of mutual comprehension of written and spoken language in Denmark, Norway and Sweden.] Stockholm: Nordiska rådet. 
Murphy, Shirin. 2003. Second language transfer during third language acquisition. Working Papers in TESOL and Applied Linguistics 3(2). 1-21.

Odlin, Terence. 1989. Language transfer. Cambridge: University Press.

Ringbom, Håkan. 1987. The role of the first language in foreign language learning. Clevedon: Multilingual Matters.

Sandoval, Tiffany. C., Tamar H. Gollan, Victor S. Ferreira \& David. P. Salmon. 2010. What causes the bilingual disadvantage in verbal fluency? The dual-task analogy. Bilingualism: Language and Cognition 13(2). 231-252.

Schüppert, Anja, Nanna H. Hilton \& Charlotte Gooskens. To appear. Swedish is beautiful, Danish is ugly. Investigating the link between language attitudes and intelligibility. Linguistics 53(2).

Selinker, Larry \& Beatrice Baumgartner-Cohen. 1995. Multiple language acquisition: 'Damn it, why can't I keep these two languages apart?' Multilingualism and Language Learning 8(2). $115-123$.

Singh, Rajendra \& Susanne Carroll. 1979. L1, L2 and L3. Indian Journal of Applied Linguistics 5. 51-63.

Tang, Chaoju \& Vincent J. J. P. van Heuven (to appear). Predicting mutual intelligibility of Chinese dialects from multiple objective linguistic distance measures. Linguistics 52(3).

Tremblay, Marie-Claude. 2006. Cross-linguistic influence in third language acquisition: The role of L2 proficiency and L2 exposure. CLO/OPL 34. 109-119.

Weinreich, Uriel 1953. Languages in contact. The Hague: Mouton.

\section{Appendix A. List with target words used in the experiment}

Danish words that only have cognates in Dutch

\begin{tabular}{lllll}
\hline & Danish target word & German translation & Dutch translation & English translation \\
\hline 1. & vante & Handschuh & want & mitten \\
2. & paraply & Regenschirm & paraplu & umbrella \\
3. & påske & Ostern & Pasen & Easter \\
4. & tolk & Dolmetscher & tolk & interpreter \\
5. & pakhus & Lager & pakhuis & warehouse \\
6. & gab & Gähnen & gaap & yawn \\
7. & redskab & Werkzeug & gereedschap & tools \\
8. & gylp & Hosenschlitz & gulp & zipper \\
9. & kapring & Entführung & kaping & hijack \\
10. & undervisning & Unterricht & onderwijs & education \\
11. & ligtorn & Hühnerauge & likdoorn & corn \\
12. & skur & Schuppen & schuur & shed \\
13. & passer & Zirkel & passer & pair of compasses \\
14. & forplejning & Krankenpflegung & verpleging & nursing \\
\hline
\end{tabular}


Danish words that only have cognates in German

\begin{tabular}{lllll}
\hline & Danish target word & German translation & Dutch translation & English translation \\
\hline 1. & oversætter & Übersetzer & vertaler & translator \\
2. & bogstav & Buchstabe & letter & letter \\
3. & anstrengelse & Anstrengung & inspanning & effort \\
4. & rør & Rohr & pijp, buis & tube \\
5. & rabat & Rabatt & korting & discount \\
6. & ferie & Ferien & vakantie & holiday \\
7. & afsnit & Abschnitt & alinea & paragraph \\
8. & spalte & Spalte & kolom & column \\
9. & begejstring & Begeisterung & enthousiasme & enthusiasm \\
10. & kartoffel & Kartoffel & aardappel & potato \\
11. & elfenben & Elfenbein & ivoor & ivory \\
12. & maler & Maler & schilder & painter \\
13. & fjernsyn & Fernseher & televisie & television \\
14. & anstændighed & Anstand & fatsoen & decency \\
\hline
\end{tabular}

Danish control words (no cognates in Dutch and German)

\begin{tabular}{lllll}
\hline & Danish target word & German translation & Dutch translation & English translation \\
\hline 1. & pige & Mädchen & meisje & girl \\
2. & emne & Thema & thema & topic \\
3. & dreng & Junge & jongen & boy \\
4. & lejlighed & Appartement & appartement & apartment \\
5. & værelse & Zimmer & kamer & room \\
6. & seng & Bett & bed & bed \\
7. & får & Schaf & schaap & sheep \\
8. & ørred & Forelle & forel & trout \\
9. & $ø r k e n$ & Wüste & woestijn & dessert \\
10. & kjole & Kleid & jurk & dress \\
11. & kæreste & Freund(in) & vriend(in) & boy-/girlfriend \\
12. & nøgle & Schlüssel & sleutel & key \\
13. & trussel & Drohung & dreigement & threat \\
14. & skæg & Schnurrbart & snor & moustache \\
\hline
\end{tabular}




\section{Authors' addresses}

\section{Femke Swarte}

Scandinavian Languages and Cultures

University of Groningen

Oude Kijk in 't Jatstraat 26

9712 EK Groningen, The Netherlands

f.h.e.swarte@rug.nl

Charlotte Gooskens

Scandinavian Languages and Cultures

University of Groningen

Oude Kijk in 't Jatstraat 26

9712 EK Groningen, The Netherlands

c.s.gooskens@rug.nl
Anja Schüppert

Scandinavian Languages and Cultures

University of Groningen

Oude Kijk in 't Jatstraat 26

9712 EK Groningen, The Netherlands

a.schueppert@rug.nl 